\title{
Injuriousness of Blumeria graminis and Pyrenophora tritici-repentis in wheat crops and measures of its operation monitoring
}

\author{
Alyona Kekalo*, Vladimir Nemchenko, and Anatoly Filippov \\ Ural Federal Agrarian Research Center of the Ural Branch of the Russian Academy of Sciences, \\ 620142, Yekaterinburg, Russia
}

\begin{abstract}
Blumeria graminis and Pyrenophora tritici-repentis of wheat are deleterious infections that often require operation monitoring. The probability of mass lesion of crops by phytopathogens is determined primarily by the presence of pathogens' infectious origin, favorable conditions for their development and spread and host plants susceptibility. Protection strategy and tactics should be based on each particular field and conditions of the growing season. Effective protection of wheat from powdery mildew (75-87\%) was provided by fungicides based on 2-3 active substances, especially the drug Falcon (spiroxamine + tebuconazole + triadimenol). The biological fungicide Phytosporin-M (Bacillus subtilis) provided an average biological efficiency of $58 \%$ in years with moderate wheat lesion. Operational control of wheat leaves yellow speckle is more advisable to carry out with preparations on the basis of such active substances as "azoxystrobin + epoxyconazole", "tebuconazole + propiconazole".
\end{abstract}

\section{Introduction}

Infectious plant diseases cause significant lesion to crop yields. Crops loss of grain and legumes from fungous diseases can reach up to $30 \%$ [1]. It is known that fungicide agents are widely used to protect plants from them, which suppress the growth and development of pathogens. But it should be borne in mind that the intensive use of pesticides of biocidal nature leads to chemical contamination of ecosystems, as well as the emergence of pesticide resistant forms of pathogens.

The causative agents of cereal diseases such as powdery mildew and pyrenophorosis or yellow leaf speckle are harmful infections that can lead to yield losses of $5-10 \%$ with moderate development of infections and up to $35-50 \%$ - in the years of epiphytotics $[1,2]$.

All bread and many forage and wild cereals are affected by powdery mildew. Blumeria graminis (DC.) Speer f. sp. Tritici March) is a complex species of fungus that includes specialized forms capable of infecting one or more species of cereal.

The distribution of powdery mildew is quite wide: Europe, Asia, Africa, America, Australia. In Russia, the disease is widespread, but especially harmful in the Ural and

\footnotetext{
*Corresponding author: alena.kekalo@mail.ru
} 
Volga-Vyatka regions, the North Caucasus, the Volga region, the Central Chernozem region [3]. It has economic significance in Belarus, Kazakhstan, Ukraine, Baltic States, Transcaucasia, as well as other grain-sowing regions of Eurasia [4]. Areas with cultivation of winter and spring cereals are in a special zone of phytosanitary risk, as fungi build a highly efficient "food conveyor".

Harmfulness of powdery mildew is manifested primarily in the reduction of assimilation surface and in the destruction of chlorophyll and other pigments $[1,5,6]$. Based on practical experience, it should be noted that agronomists do not often perceive plant lesion by the discussed pathogen as a crop threat as opposed to rust, for example. As a result, timely protection measures are not taken, which leads to a loss of wheat yield and decrease in grain quality.

The powdery mildew is only able to feed on living green plants. That is, while the host plant is green, until then the fungus lives as well. It releases no toxins and does not attempt to kill the plant quickly. A different relation to the host plant is shown by the pyrenophorosis pathogen, which is a necrophyte and produces host specific toxins $[4,7,8]$. These toxins induce symptoms of necrosis or chlorosis when interacting with their respective susceptibility genes [8].

Yellow leaf speckle is a relatively new wheat disease. The causative agent is ascomycete fungus Pyrenophora tritici-repentis (Died.) Drechsler. In North America and Australia, it manifested itself at the level of epiphytotics in the 1970s; in Europe (including Russia) - in the 1980s. Epiphytotics of this disease are periodically observed in different countries of the world, grain losses in susceptible varieties reach $65 \%$ [7-9].

It should be remembered that excessive attention to the creation of varieties resistant to one disease can lead to genetic vulnerability to other diseases, which has been the case previously in Canada. In addition to the given reason, the spread of yellow leaf speckle could also be facilitated by modern gentle tillage, where a large number of plant residues remain on its surface, which are habitat for wintering pseudo-perithecia $P$. tritici-repentis $[8,10]$.

Operational control of infections is carried out through treatment with fungicides. The question about their justifiable use is not easy to answer, as their application is an investment in an often unpredictable future. In order for protective measures to be justified, it is necessary to make targeted fungicides introduction, taking into account the tension level of phytosanitary situation, the range of preparation action, price categories for grain and pesticides. Numerous scientific (own and literary) data show that a particular reserve of infection may not always lead to the mass development of the disease. Monitoring of phytopathogens development and weather conditions of the growing period is important.

The aim of the research was to determine the development level of powdery mildew and pyrenophorosis on spring wheat (Triticum aestivum L.) and to determine the effectiveness of fungicide preparations for control of leaf phytopathogens.

\section{Materials and Research Methods}

The research was carried out in the laboratory of plant growth regulators and plant protection of the Kurgan Research Institute of Agriculture - branch of the Ural Federal Agrarian Scientific- Research Center of the Ural Branch of the Russian Academy of Sciences (UrFASRC UrB RAS) within the framework of the State Order of the Ministry of Education of Russia in the direction of 153 of the Program of the National Science Academies on the topic "Improve the system of integrated plant protection in resourcesaving technologies on the basis of unilateral application of biological and chemical means of plant protection of new generation and integrated use with growth regulators and top dressing" in 2009-2019. In the experiments, spring soft wheat (Triticum aestivum L.) of 
the Omskaya 36 variety was used. The precursor of spring wheat was pure early fallow. The soil of the experimental site is leached medium-humus medium-clay chernozem. Processing of crops with fungicides was carried out in the phase of the flag coming out (f.37 according to Zadoks) using the sprayer "Solo 456", working solution consumption $300 \mathrm{l} / \mathrm{ha}$. The area of the plot is $20 \mathrm{~m}^{2}$, the repetition is 4 times, the placement of the plots is systematic. To eliminate the influence of weeds, background processing of experiment with tank mix of herbicides "2.4-D + tribenuron-methyl + phenyxaprop-P-ethyl" (Ballerina 0.35 $\mathrm{l} / \mathrm{ha}+$ Granat $15 \mathrm{~g} / \mathrm{ha}+$ Ocelot $0.8 \mathrm{l} / \mathrm{ha}$ ) in the tillering phase was performed.

Observations and accounts were carried out according to the methods generally accepted in the Russian Federation [11-13].

The experiment scheme included the following fungicides: propiconazole $250+$ ciproconazole $80 \mathrm{~g} / \mathrm{L}$ (Alto super), spiroxamine $250+$ tebuconazole $167+$ triadimenol 43 $\mathrm{g} / \mathrm{L}$ (Falcon), propiconazole $300+$ tebuconazole $200 \mathrm{~g} / \mathrm{L}$ ( Colosal PRO), thiophanatemethyl $310+$ epoxyconazole $187 \mathrm{~g} / \mathrm{L}$ (Rex Duo), propiconazole $140+$ tebuconazole $140+$ epoxyconazole $72 \mathrm{~g} / \mathrm{L}$ (Triada), tebuconazole $225+$ flutriafol $75 \mathrm{~g} / \mathrm{L}$ (Strike Forte), propiconazole $390 \mathrm{~g} / \mathrm{L}$ (Titul 390), cyproconazole $400 \mathrm{~g} / \mathrm{L}$ (Recrut), tebuconazole $250 \mathrm{~g} / \mathrm{L}$ (Chancil), azoxystrobin $240+$ epoxyconazole $160 \mathrm{~g} / \mathrm{L}$ (Spirit), Bacillus subtilis, 26D strain (Phytosporin-M, F)

\section{Research results}

The control issues of leaf speckle are relevant in almost every crop season. In the modern realities, when traditional moulding technologies of soil processing are replaced with resource-saving and water-saving systems (mini-till, no-till), stock of infectious diseases initiations of plants such as powdery mildew, pyrenophorosis, septoriosis, fusarium, etc. is successfully preserved in the field on stubble residues.

Monitoring of the fungal infections development on wheat leaves showed that over the period of 2009-2019 the degree of plant lesion more than $20 \%$ in the earing phase was observed in $46 \%$ of the years of observations (in 2009, 2013, 2014, 2016 , 2017). Virtually every year powdery mildew was feeding on wheat, the primary symptoms of the lesion were usually observed at the end of the stalk-shooting phase (f. 34-36 on Zadoks). Epiphytotic development of brown leaf rust together with powdery mildew took place in 2013-2014 and 2016-2017. In recent years, during flowering - grain formation there was still a lesion of straw with stem rust (Puccinia graminis Pers. f. sp. tritici Erikss. et Henn. ).

Field experiments showed that combinations of fungicidal agents such as azoxystrobin $240+$ epoxyconazole $160 \mathrm{~g} / \mathrm{l}$, propiconazole $300+$ tebuconazole $200 \mathrm{~g} / \mathrm{l}$, methyl thiophanate $310+$ epoxyconazole $187 \mathrm{~g} / \mathrm{l}$, and tebuconazole based drug (table 1) provided good biological efficiency (more than 80\%) for pyrenophorosis. Weak control of Pyrenophora tritici-repentis was observed on variants with single component fungicides based on cyproconazole and propiconazole $(38.0-45.6 \%)$ (Table 1$)$.

Table 1. Lesion of spring wheat with Pyrenophora tritici-repentis depending on the use of fungicide drugs, 2018-2019

\begin{tabular}{|l|c|c|c|}
\hline \multicolumn{1}{|c|}{ Option } & $\begin{array}{c}\text { Development } \\
\text { of disease } \\
\text { during } \\
\text { grain formatio } \\
\text { n period (f. } \\
71-73), \%\end{array}$ & $\begin{array}{c}\text { Biological } \\
\text { efficiency } \\
\text { of the drug, } \\
\%\end{array}$ & $\begin{array}{c}\text { Disease } \\
\text { spread during } \\
\text { grain } \\
\text { formation (f. } \\
71-73), \%\end{array}$ \\
\hline Control without fungicidal treatment & 3.89 & - & 75.0 \\
\hline Propiconazole $390 \mathrm{~g} / \mathrm{l}$ (Titul 390 0.26 1/ha) & 2.12 & 45.6 & 72.5 \\
\hline
\end{tabular}




\begin{tabular}{|l|c|c|c|}
\hline Cyproconazole $400 \mathrm{~g} / \mathrm{l}$ (Recrut 0.2 1/ha) & 2.41 & 38.0 & 75.0 \\
\hline Tebuconazole 250 g/1 (Chancil 1 1/ha) & 0.60 & 84.5 & 80.0 \\
\hline $\begin{array}{l}\text { Propiconazole 250 + ciproconazole 80 g/1 (Alto } \\
\text { Super 0.4 1/ha) }\end{array}$ & 1.17 & 69.9 & 76.5 \\
\hline $\begin{array}{l}\text { Propiconazole 300 + tebuconazole 200 g/l } \\
\text { (Colosal PRO 0.4 1/ha) }\end{array}$ & 0.62 & 84.2 & 63.5 \\
\hline $\begin{array}{l}\text { Thiophanate-methyl 310+ epoxyconazole 187 } \\
\text { g/l (Rex Duo 0.5 1/ha) }\end{array}$ & 0.73 & 81.2 & 67.5 \\
\hline $\begin{array}{l}\text { Tebuconazole 225 + flutriafol 75 g/l (Strike } \\
\text { forte 0.5 1/ha) }\end{array}$ & 1.00 & 74.4 & 75.5 \\
\hline $\begin{array}{l}\text { Azoxystrobin 240 + epoxyconazole 160 g/l } \\
\text { Spirit 0.6 1/ha) }\end{array}$ & 1.00 & 94.4 & 45.0 \\
\hline $\begin{array}{l}\text { Spiroxamine 250 + tebuconazole 167 + } \\
\text { triadimenol 43 g/1 (Falcon 0.6 1/ha) }\end{array}$ & 1.83 & 53.0 & 82.5 \\
\hline $\begin{array}{l}\text { Propiconazole 140 + tebuconazole 140 + } \\
\text { epoxyconazole 72 g/1 (Triada 0.6 1/ha) }\end{array}$ & 0.79 & 79.7 & 71.0 \\
\hline $\begin{array}{l}\text { Bacillus subtilis, strain 26D (Phytosporin-M 1 } \\
\text { 1/ha) }\end{array}$ & 4.14 & 5.4 & 70.0 \\
\hline
\end{tabular}

The prevalence of infections during the earing-flowering period of wheat was reduced only with the drug based on azoxitsrobin with epoxyconazole up to $45 \%$.

Primary signs of wheat lesion with powdery mildew were fixed in the stalkshooting phase. The further rate of infection development was directly dependent on hydrothermal conditions. Multi-year evidence suggests that Blumeria graminis development was in a close positive relationship $(\mathrm{r}=0.77-0.82)$ with precipitation and a noticeable negative $(\mathrm{r}=-0.65-0.70)$ relationship with temperature in periods from tillering to flag leaf coming out and from earing to flowering.

Biological efficiency of chemical fungicides was observed as good (over 70\%) in years with moderate to mass plant lesions. Biological fungicide in conditions of epiphytotia and depression did not cope with protective function (33-35\% technical efficiency).

Table 2. Biological effectiveness of fungicide drugs at different levels of wheat lesion with powdery mildew, 2009-2017.

\begin{tabular}{|c|c|c|c|c|c|c|}
\hline \multirow[t]{2}{*}{ Option } & \multicolumn{2}{|c|}{$\begin{array}{c}\text { Epiphytotia of leaf } \\
\text { infections }(2009, \\
2013,2014,2016, \\
2017)\end{array}$} & \multicolumn{2}{|c|}{$\begin{array}{c}\text { Moderate } \\
\text { development of } \\
\text { infections (2011, } \\
\text { 2015) }\end{array}$} & \multicolumn{2}{|c|}{$\begin{array}{l}\text { Depression } \\
(2018,2019)\end{array}$} \\
\hline & $\mathrm{R}, \% *$ & $\begin{array}{l}\mathrm{BE} \\
\% * *\end{array}$ & $\mathrm{R}, \%$ * & $\begin{array}{l}\mathrm{BE} \\
\% * *\end{array}$ & $\mathrm{R}, \%$ * & $\begin{array}{l}\mathrm{BE}, \\
\% * *\end{array}$ \\
\hline $\begin{array}{l}\text { Control without fungicidal } \\
\text { treatment }\end{array}$ & 38.9 & - & 10.0 & - & 3.4 & - \\
\hline $\begin{array}{lrrr}\begin{array}{l}\text { Propiconazole } \\
\text { ciproconazole }\end{array} & 80 & \text { g/l } & \text { (Alto } \\
\text { Super } 0.4 \text { l/ha) } & & & \\
\end{array}$ & 9.9 & 75 & 2.3 & 77 & 1.1 & 68 \\
\hline $\begin{array}{llr}\text { Propiconazole } & 300 & + \\
\text { tebuconazole } 200 & \mathrm{~g} / \mathrm{l} \text { (Colosal } \\
\text { PRO } 0.4 \mathrm{l} / \mathrm{ha}) & & \end{array}$ & 9.1 & 77 & 2.2 & 78 & 0.9 & 74 \\
\hline 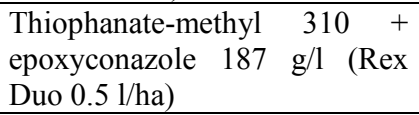 & 8.6 & 78 & 2.1 & 79 & 1.6 & 53 \\
\hline $\begin{array}{l}\text { Spiroxamine } \quad 250 \\
\text { tebuconazole } 167+\text { triadimenol } \\
43 \mathrm{~g} / \mathrm{l}(\text { Falcon } 0.6 \mathrm{l} / \mathrm{ha})\end{array}$ & 5.1 & 87 & 2.3 & 77 & 1.7 & 50 \\
\hline
\end{tabular}


Bacillus subtilis, strain 26D (Phytosporin-M 1 1/ha)

Note: $\mathrm{R}^{*}$ - development of disease in the period of earing- flowering (f. 55-65 Zadoks);

$\mathrm{BE}^{* *}$ - biological effectiveness of the preparation according to the Abbot formula

In 2011 and 2015, the degree of plant lesion was characterized as moderate development (10\% in f. 51-61). During these years, the use of fungicides in wheat crops had a lower payback than in mass lesion. The biological effectiveness of the chemical fungicides studied was $77-79 \%$, which is almost at the level of infections mass development over the years. The biological drug with moderate development of powdery mildew reduced the degree of plant lesion by $58 \%$. In these years there were fewer dry events in the second half of vegetation and bacteria inoculated more effectively on the leaves of wheat than in the scarcity of moisture.

During the years of mass development of aerogenic infections, timely fungicide treatments retained a significant part of the grain crop and quality. Correlation dependence of yield and degree of disease lesion was characterized as severe negative $(\mathrm{r}=-0.94)$ during the years of mass development of infections. With a moderate lesion of plants, the dependence tightness decreased $(\mathrm{r}=-0.85)$

The biological effectiveness of fungicidal preparations with respect to total lesions of all leaf infections was characterized as good - $66-68 \%$ on Titul 390 and Recrut variants and high - $80-90 \%$ when treated with preparations based on 2-3 active substances. Phytosporin-M has, on average, controlled leaf disease by $40 \%$ over years of research.

The yield of spring wheat in the experiment averaged over the years of research to 21.9 /ha (from $10 \mathrm{dt} / \mathrm{ha}$ in extreme arid years 2010 and 2012 to $39 \mathrm{dt} / \mathrm{ha}$ - in favorable 2011), which is for conditions of moisture availability of the growing period $175-200 \mathrm{~mm}$ is good productivity.

Due to fungicide protection, the level of retained crop was 5-6\% during the depression years, $18 \%$ of the yield was maintained with moderate development of leaf diseases due to chemical fungicides, and biopreparation provided an increase in productivity of $9 \%$ to control. During the epiphytotics years, chemical protection of crops maintained an average of $24 \%$ of wheat yield, the best performance and stability of action had polycomponent preparations.

\section{Conclusions}

Wheat powdery mildew and pyrenophorosis are malicious infections that often require operational control. The probability of mass lesion of crops by pathogens is determined primarily by the presence of infectious pathogens origin, favorable conditions for their development and spread, as well as susceptibility of host plants. Protection strategy and tactics should be based on each particular field and conditions of the growing season.

Effective protection of wheat from powdery mildew $(75-87 \%)$ was provided by fungicides based on 2-3 active substances, especially the Falcon preparation (spiroxamine + tebuconazole + triadimenol). Biofungicide provided a medium biological efficiency in years with moderate wheat lesion.

Operational control of yellow leaf speckle is more advisable to carry out by preparations based on such active substances as azoxystrobin + epoxyconazole, propiconazole + tebuconazole. Biofungicide did not control a given type of infection. 


\section{References}

1. S.L. Tyuterev, Mechanisms of fungicides action on phytopathogenic fungi, 172 (St. Petersburg: VIZR, 2010)

2. S.S. Sanin, Protection and quarantine of plants, 4, 3-6 (2016)

3. S.S. Sanin, Protection and quarantine of plants, 5, 83-88 (2016)

4. O.Yu. Kremneva, G.V. Volkova, Mycology and phytopathology, 41 (4), 356-361 (2007)

5. M.M. Levitin, Agricultural Biology, 50 (5), 641-647 (2015) DOI: 10.15389/agrobiology.2015.5.641rus

6. M. Koishibayev, Wheat diseases (Ankara, 365, 2018)

7. N.V. Vasilyeva, V.E. Sineshchekov, Bulletin of NSAU, 2 (31), 7-13 (2014)

8. L.A. Mikhailova, I.G. Ternyuk, N.V. Mironenko, Mycology and phytopathology, 44 (3), 262-268 (2010)

9. V.V. Evseev, Pyrenophorosis of wheat in the forest-steppe of Southern Urals, 148 (Beau Bassic: LAP LAMBERT Academic Publishing, 2018)

10. L. Lamari, B.D. McCallum, R.M. DePauw, Phytopathology, 95 (2), 144-152 (2005a)

11. Ecological monitoring and improvement methods of grain crops protection from pests, diseases and weeds: methodological recommendations, under ed. of V.I. Tansky, 76 (St. Petersburg: VIZR, 2002)

12. Methods of state variety testing of crops, 239 (M.: Kolos, 1989)

13. Methodical instructions for registration tests of fungicides in agriculture, 378 (St.Petersburg. VIZR, 2009) 